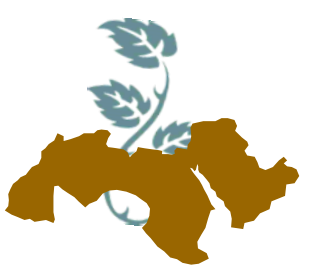

Arab Univ.

J. Agric. Sci., Ain Shams Univ., Cairo, 25(2), 339-348, 2017

\title{
SOME PHYSIOLOGICAL AND BIOCHEMICAL EFFECTS OF ABAMECTIN AND PYRIPROXYFEN AGAINST THE PINK BOLLWORM, Pectinophora gossypiella (Saund.)
}

\author{
Youssef, L.A. \\ Plant Protection Dept. Faculty of Agriculture, Ain Shams University, Cairo, Egypt
}

Keywords: Pink bollworm, Pectinophora gossypiella, Abamectin, Pyriproxyfen. $\beta$-esterase enzyme

\section{ABSTRACT}

The toxic effect of Abamectin and Pyriproxyfen action on the $1^{\text {st }}$ instar larvae of the pink bollworm, Pectinophora gossypiella (Saund.) was studied under laboratory conditions. The toxic action of the tested compounds at their estimated $\mathrm{LC}_{50}$ values on some biological aspects of the treated insect as well as total protein content and the activity of $\beta$ esterase in the affected larvae were also studied. Based on the obtained results, abamectin was more toxic than pyriproxyfen after 24,48 and $72 \mathrm{hr}$ of treatment. In addition, the effect of treatment with the $\mathrm{LC}_{50}$ value of both tested compounds on newly hatched larvae was extended to the following developmental stages, represented as some morphological deformities. Also, total protein content in treated larvae increased than their control when Pyriproxyfen was tested but decreased when Abamectin was administered to larval diet. The electrophoretic analysis using SDS-PAGE for $\beta$ esterase enzyme in the larval stage fed on diets treated with tested compounds showed clear variation in the dense and number of enzyme bands.

\section{INTRODUCTION}

Cotton is an important economic major crop as its production and processing are considered principle economical agricultural crops in Egypt. But its is highly susceptible to infestation by large number of insect pests of which the Egyptian cotton leaf worm and the pink bollworm are major pests, reducing both the quantity and quality of the cotton harvest (Oerk et al 1994). Great efforts are con- tinuously been made to control insect pests mainly by the use of insecticides the majority of which are usually highly toxic and non-specific, hazardous to humans, animals and environment. In addition, insect pests themselves may survive insecticides treatment by developing resistance to chemicals.

The present study was undertaken to evaluate the effects of two insecticides on Pectinophora gossypiella (Saund.) (Lepidoptera: Gelechiidae) larvae. The pesticides are: (i) Abamectin, with the commercial name Vertimic. (ii) Priproxyfen, with the commercial name Admiral.

These chemicals present two groups, the former is a biocide and the latter is a juvenile hormone mimic. Vertimec is one of natural pesticides from family Avermectins, a lactone natural product produced by soil microorganisms Streptomyces avermitilis. Avermectin $B_{1}$ is the most important because it has high potency against a broad spectrum of endoparasites and ectoparasites of farm animals and many agricultural mite and insect pests (Campbell, 1989). Pyriproxyfen is an IGR, a synthetic juvenoids that may mimic or duplicate the insect natural juvenile hormone (KryspinSorensen et al 1977 and Staal, 1982).

It was reported that many chemicals used in the control of insects e.g. diflubenzuron, pyriproxyfen and abamectin, cause a significant alteration of different enzymatic activities in insects, i.e. esterase, chitinase and penoloxidase (Mostafa, 1993; Farag, 2001 and RaymoundDelpeeh et al 2005). Furthermore, such chemicals as well as their formulated application exhibit a relative short environmental persistence and low mammalian toxicity (Quistad et al 1974; Halley et al 1993 and Dhadialla et al 1998).

The present investigation was undertaken to evaluate the effect of Abamectin, Pyriproxyfen on the larval stage of the pink bollworm Pectinophora 
gossypiella. (Saund.). Biochemical changes, mainly in regard total protein content and $\beta$-esterase enzyme activity was considered in both treated and untreated larvae.

\section{MATERIALS AND METHODS}

\section{Insecticides used:}

Two insecticides were tested: Abamectin (Vertemic $\left.^{\circledR}\right)\left(1.8 \%\right.$ EC) and Pyriproxyfen (Admiral ${ }^{\circledR}$ ) $(10 \% E C)$ which were obtained from Sumitomo Chemical Co. Cairo, Egypt.

\section{Insect rearing technique}

Larvae of pink bollworm, Pectinophora gossypiella (Lepidoptera: Gelechiidae) were reared under laboratory conditions of $25^{\circ} \mathrm{C} \pm 2$ and $60 \% \pm 5$ $\mathrm{RH}$ on an artificial kidney bean diet as described by Abdel-Hafez et al (1982). This artificial diet consisted of $215 \mathrm{gm}$ kidney beans boiled in water, $32 \mathrm{gm}$ dried active yeast, $3 \mathrm{gm}$ ascorbic acid, 1.5 gm sorbic acid and $12 \mathrm{gm}$ agar, to which $150 \mathrm{ml}$ water was added. The prepared larval diet was placed in glass tubes measuring $2 \times 7.5 \mathrm{~cm}$ at a rate of $4 \mathrm{gm}$ diet/ tube. Newly hatched (neonate) $P$. gossypiella larvae were placed on the surface of the prepared artificial diet.

\section{Bioassay of the tested insecticides}

Serial of five concentrations, i.e. 2.50, 1.25, $0.62,0.31$ and $0.15 \mathrm{ppm}$ of each tested compounds was prepared using distilled water. Each concentration was sprayed into petri dishes $(9 \mathrm{~cm}$ diam.) using a hand atomizer. Treated surfaces were left to dry. Thirty neonates were transferred with a clean brush to each treated dish. The dishes were covered with toilet paper then further covered with their covers and kept at $25^{\circ} \mathrm{C} \pm 2$ and $60 \% \pm 5$ $\mathrm{RH}$. After an exposure periods of 24,48 and $72 \mathrm{hr}$ treated larvae were transferred individually on the mentioned artificial diet poured into glass tubes (2 $x 7.5 \mathrm{~cm}$ ) which were then covered with cotton wool and kept under the previous mentioned constant laboratory conditions. Each concentration per each chemical was replicated three times. Mortality was recorded after 24, 48 and 72 hour. Percentage mortalities were corrected according Abbott's formula (1925). Toxicity regression lines were represented on log / probit paper according to Finney, (1972). LC $50, L_{90}$ and slope values were estimated.

\section{Biological studies}

Thirty newly hatched larvae of $P$. gossypiella were used to study the effect of each of Abamectin or Pyriproxyfen on some biological aspects of treated insect. Larval mortality was recorded every 48 hours and up to their pupation following their feeding on the artificial diet treated with $\mathrm{LC}_{50}$ of either Abamectin or Pyriproxyfen and up to pupation. Soon after pupation, pupae were collected, sexed and then maintained individually up to adult emergence. The following biological aspects were recorded for each tested chemicals:

(i) longevity of larval stage

(ii) percentage of pupation

(iii) percentage of emerged moths

(iv) Insects were scored for any induced developmental abnormalities in larvae, pupae or adult moths.

(v) Percentage accumulative mortalities in each treatment was corrected by Abbott's formula (Abbott 1925).

\section{Determination of total protein}

Total protein content was determined in $4^{\text {th }}$ instar $P$. gossypiella larvae reared since hatching on the adopted artificial media to which Abamectin or Pyriproxyfen was added at their determined LC50 value.

Total protein was estimated spectrophotometrically by the method described by Bradford (1976). Protein was extracted from homogenized $4^{\text {th }}$ instar larval tissues and prepared for assay as described by Lewis et al (1994). Protein determination in this method depends upon binding of Coomassie Brilliant Blue G-250 dye to protein. It is based on the observation that Coomassie Brilliant Blue G-250 exists in two different color forms (red and blue). Sample solution $(100 \mathrm{ml})$ was added to $100 \mathrm{ml}$

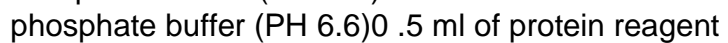
were added to the test tube and the contents were mixed well either by inversion of vortexing. The absorbance of $595 \mathrm{~nm}$ was measured after 2 minutes and before 1 hour, against a blank prepared from $200 \mathrm{ml}$ phosphate buffer (PH 6.6) and $5 \mathrm{ml}$ of protein reagent. The red form is converted to the blue form upon binding of the dye with protein. The protein-dye complex has a high extinction coefficient thus leading to great sensitivity in measurement of the protein. The binding of the dye to protein is a very rapid process (approximately 2 minutes), and the protein-dye complex remains dispersed in solution for a relative long time (approximately 1 hour). The binding of the dye to protein causes a shift in the absorption at $595 \mathrm{~nm}$ which is monitored. 


\section{Electrophorestic study of $\beta$-esterase}

For the extraction of larval isozymes ten $4^{\text {th }}$ instar P.gossypiella larvae were reared for 72 hours on artificial diet treated with the determined $\mathrm{LC}_{50}$ of either Abamectin or Pyriproxyfen. The larvae were homogenized in buffer for isozymes and centrifuged at $10000 \mathrm{rpm} / 10 \mathrm{~min}$. The supernatants were transferred to clean Eppendorf tubes and were mixed with bromophenol blue as a tracking dye. $8 \%$ polyacrylamide standard gel ph 8.6 as described by Gaaboub et al (2012). the gel was poured on the plate and 15 well combs were pieced immediately.

\section{Enzymes Assay}

The gels were stained by staining solution. The staining solutions are: $100 \mathrm{mM}$ Na phosphate, $\mathrm{PH}$ $6.050 \mathrm{ml}, \beta$ naphthyl acetate $50 \mathrm{ml}$, Fast blue $\mathrm{RR}$ salt $2.5 \mathrm{ma}$ ) after electrophoresis and incubated at $37^{\circ} \mathrm{C}$ in darkness for complete staining after adding the appropriate substrate and the gel was washed rapidly in two or three changes of distilled water to stop the reaction. This was followed by adding the fixing solution, which consists of 9 parts of ethanol and 11 parts of $20 \%$ glacial acetic acid. The gel was kept in the fixing solution for 24 hours subsequently it was rinsed with distilled water two times before being photographed.

\section{Results \\ Bioassay}

According to toxicity regression lines (Table 1, Figs. $1 \& 2$ ), and based on the calculated LC50 values, both tested compounds exhibited an insecticidal activity to $1^{\text {st }}$ instar larvae of $P$. gosseipiella. Abamectin exhibited a higher toxicity than Pyripproxyfen against the $1^{\text {st }}$ instar larvae after 24, 48 and $72 \mathrm{hr}$ following treatment. The calculated $\mathrm{LC}_{50}$ values were $0.51,0.47$ and $0.44 \mathrm{ppm}$. Meanwhile, LC50 values Pyriproxyfen were 1.74, 1.29, and $1.21 \mathrm{ppm}$ after 24,48 and $72 \mathrm{hr}$, respectively. The $\mathrm{LC}_{90}$ values followed a similar trend, as Abamectin again exhibited higher toxicity than Pyriproxyfen at such parameter, i.e. 9.04, 8.99 and 6.92 ppm for Abamectin and 273.91, 169.16 and 161.01 ppm for Pyriproxyfen after 24, 48 and $72 \mathrm{hr}$, respectively.

Both toxicity index and relative potency values based on the determined LC $_{50}$ were 1.66, 1.23 and 1.16after 24, 48 and $72 \mathrm{hr}$, respectively, for pyriproxyfen and $0.74,0.67$ and 0.63 for abamectin, respectively. Also, the values of LC50/ LC90 ratio were $0.0063,0.0017$, and 0.0075 after 24,48 and $72 \mathrm{hr}$ for pyriproxyfen, $0.0564,0.0517$ and 0.0631 for abamectin, respectiviely. In addition, the slope values of pyriproxyfen was a higher than that of abamectin. Such difference in the slope values may be due to the slow action of pyriproxyfen compared to the relatively rapid action of abamectin.

Table 1. Toxicity values of Abamectin and Pyriproxyfen on $1^{\text {st }}$ instar larvae of Pectinophera gossypiella

\begin{tabular}{|c|c|c|c|c|c|c|}
\hline \multirow{2}{*}{ Compound } & \multicolumn{3}{|c|}{ abamectin } & \multicolumn{3}{c|}{ pyriproxyfen } \\
\cline { 2 - 7 } & $24 \mathrm{hrs}$. & $48 \mathrm{hrs}$. & $72 \mathrm{hrs}$. & $24 \mathrm{hrs}$. & $48 \mathrm{hrs}$. & $72 \mathrm{hrs}$. \\
\hline LC50 ppm & 0.51 & 0.47 & 0.44 & 1.74 & 1.29 & 1.21 \\
LC90 ppm & 9.04 & 8.99 & 6.92 & 273.91 & 169.17 & 161.02 \\
Slope & 19.91 & 18.49 & 19.91 & 18.28 & 24.36 & 24.36 \\
Toxicity index(Ti) based on LC50 & 0.74 & 0.67 & 0.63 & 1.66 & 1.23 & 1.16 \\
Relative potency based on LC50 & 0.01 & 0.01 & 0.01 & 0.03 & 0.019 & 0.018 \\
\hline LC50/ LC90 ratio & 0.0564 & 0.0517 & 0.0631 & 0.0063 & 0.0017 & 0.0075 \\
\hline
\end{tabular}

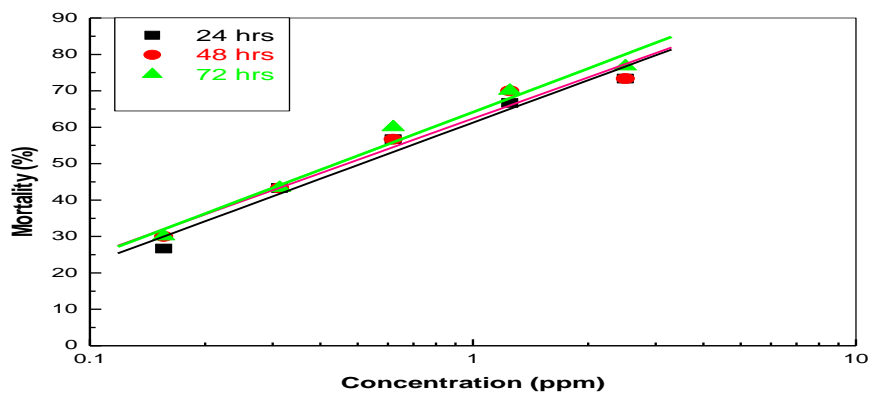

Fig. 1. Toxicity regression line of abamectin against the first larval instar of Pectinophra gossypiella after 24,48 and $72 \mathrm{hr}$. 


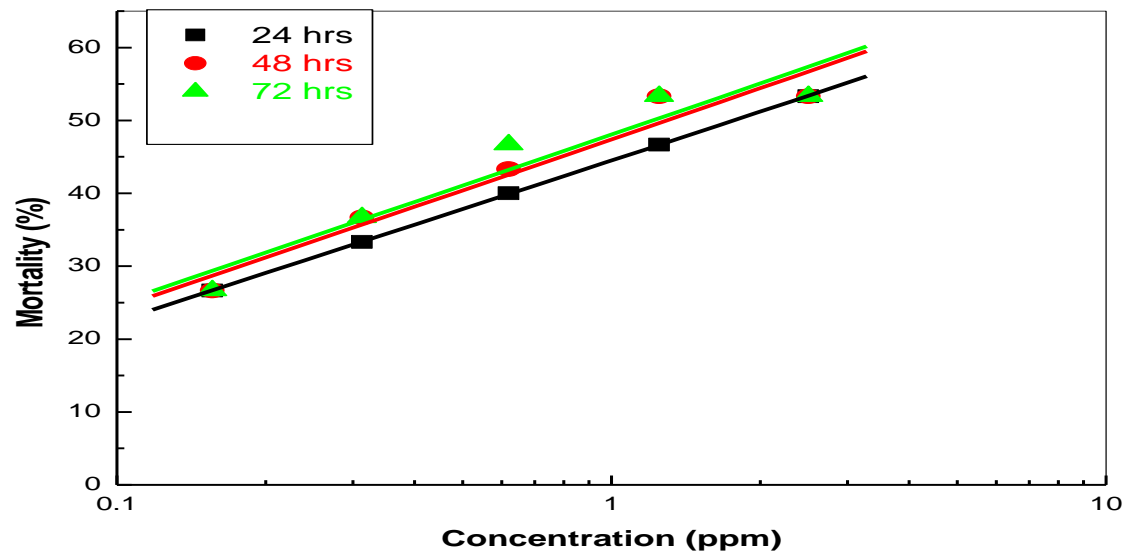

Fig. 2. Toxicity regression line of pyriproxyfen against the first larval instar of Pectinophra gossypiella after 24, 48 and $72 \mathrm{hr}$

\section{Effect of tested chemicals on the biology of the pink bollworm $P$. gossypiella}

\section{Effect on the larval stage}

Abamectin and Pyriproxyfen applied at the determined $\mathrm{LC}_{50}$ concentration added to $1^{\text {st }}$ instars larval artificial diet after 24 hours, caused 44.44 and $40.74 \%$ larval corrected mortality, respectively. This percentage did not increase hereafter, (Table 2). Incidence of malformed larvae to the respective mentioned chemicals was 13.33 and $7.14 \%$. The rate of increment than control in larval mortality following their treatment with $L_{50}$ values of Abamectin and Pyriproxyfen were similar, (i.e. 80 and $78,57 \%$, respectively, (Table 2).

As a result of adding Abamectin or Pyriproxyfen to larval diet several morphological malformation were induced in treated larvae (Figs. 3, 4, 5 \& 6). Larvae treated with $L_{50}$ of Pyriproxyfen led to an increase in the size of some treated larvae and Changes in external shape and size than their control. Other exhibited symptoms, in pyriproxyfen exhibited symptoms that start at the anterior part of the body (thoracic area) and spread gradually backward to the posterior part of the larval body. Also caused an increase in the size In addition, some treated larvae appeared pale in color (Fig.4 a). Malformations caused by treatment of $1^{\text {st }}$ inster with LC50 of abamectin include stretched abdomens, larval cuticle transformed to black scales. Also shrinkage of ventral side of the abdomen leading to a curvature shape "cresent shape".Some larvae appeared with a soft oily cuticle, with brown patches on the body (Fig. 4 b).

\section{Effect on the pupal stage}

As seen in Table 3, $\mathrm{LC}_{50}$ of Abamectin and Pyriproxyfen applied to the artificial diet of $P$. gossypiella $1^{\text {st }}$ instar larvae exhibited a latent effect in surviving insects at pupation as percentage pupation was reduced to 73.33 and $56.25 \%$, respectively. The duration of the pupal stage of larvae surviving treatment with $\mathrm{LC}_{50}$ Abamectin was comparable to that of the control i.e. 7.91 and 7.89 days, respectively. However, LC $_{50}$ Pyriproxyfen significantly increased pupal stage to 11.22 days.

It is noteworthy that morphological malformation of pupae was evident following their feeding on a diet treated with either of the tested chemicals leading to their failure to emerge as moths. This effect was more evident when $L_{50}$ Pyriproxyfen was administered as compared to the application of $\mathrm{LC}_{50}$ Abamectin to larval diet; i.e. was 43.75 and $26.67 \%$, to the respect mentioned chemicals.

Some pupa appeared with different pigmentation on their cuticle, furthermore, in some pupae sex differentiation was difficult (Fig. 5 a). Some of larvae fed on a diet treated with $\mathrm{LC}_{50}$ Abamectin appeared with impaired formation of their wings or with emaciation at the abdominal end, (Fig. 5 b).

\section{Effect on the adult stage}

Percentage $P$. gossypiella adult emergence in the control was $100 \%$. This percentage was slightly reduced to 81.89 and $88.89 \%$ when larvae were fed on a diet containing $\mathrm{LC}_{50}$ Abamectin or Pyriproxyfen, respectively (Table 5). Percentage induced moth malformation in moths was $18.18 \%$ 

bollworm, Pectinophora gossypiella (saund.)

Table 2. Effect of Abamectin and Pyriproxyfen on some biological aspects of the pink bollworm, Pectinophora gossypiella larvae.

\begin{tabular}{|c|c|c|c|c|c|c|c|c|c|c|c|c|}
\hline Aspect & \multicolumn{5}{|c|}{$\mathrm{N}^{\circ}$ of larval after (days) } & \multirow{2}{*}{ Total } & \multirow{2}{*}{$\begin{array}{l}N^{\circ} \text {. mal- } \\
\text { formd } \\
\text { larva }\end{array}$} & \multirow{2}{*}{$\begin{array}{l}\text { Correctd } \\
\text { mortality } \\
(\%)\end{array}$} & \multirow{2}{*}{$\begin{array}{l}\text { Malformd } \\
\text { larva (\%) }\end{array}$} & \multirow{2}{*}{\begin{tabular}{|c|} 
Larval \\
stage \\
duration \\
/day
\end{tabular}} & \multirow{2}{*}{$\begin{array}{l}\text { Reductin in } \\
\text { larval stage } \\
(\%)\end{array}$} & \multirow{2}{*}{$\begin{array}{c}\text { Rate of } \\
\text { increament } \\
\text { of mortality }\end{array}$} \\
\hline Formulation & 1 & 3 & 5 & 7 & 9 & & & & & & & \\
\hline Abamectin $\mathrm{LC}_{50}$ & 14 & 1 & 0 & 0 & 0 & 15 & 2 & 44.44 & 13.33 & 1.13 & 73.9 & 80 \\
\hline Pyriproxyfen $\mathrm{LC}_{50}$ & 13 & 0 & 0 & 1 & 0 & 14 & 1 & 40.74 & 7.14 & 1.43 & 66.97 & 78.57 \\
\hline Control & 1 & 0 & 1 & 1 & 0 & 3 & 0 & - & 0 & 4.33 & - & _ \\
\hline
\end{tabular}

Table 3. Effect of Abamectin, Pyriproxyfen at $\mathrm{LC}_{50}$ values on some biological aspects of the pink bollworm, Pectinophora gossypiella pupae.

\begin{tabular}{|c|c|c|c|c|c|c|c|c|c|c|c|c|}
\hline \multirow{2}{*}{$\begin{array}{c}\text { aspect } \\
\text { Formulation }\end{array}$} & \multicolumn{6}{|c|}{ Number of pupal after (days) } & \multirow[b]{2}{*}{ Total } & \multirow{2}{*}{$\begin{array}{l}\% \text { pupa- } \\
\text { tion }\end{array}$} & \multirow{2}{*}{$\begin{array}{c}\text { mal- } \\
\text { formed } \\
\text { pupae } \\
\% \\
\end{array}$} & \multirow{2}{*}{$\begin{array}{l}\text { pupal } \\
\text { stage / } \\
\text { day }\end{array}$} & \multirow{2}{*}{$\begin{array}{c}\text { Reduction } \\
\text { in pupa- } \\
\text { tion stage } \\
(\%)\end{array}$} & \multirow{2}{*}{$\begin{array}{c}\text { Rate of } \\
\text { increament } \\
\text { in pupal } \\
\text { stage }\end{array}$} \\
\hline & 7 & 9 & 11 & 13 & 15 & 17 & & & & & & \\
\hline $\begin{array}{c}\text { Abamectin } \\
\text { LC }_{50}\end{array}$ & 6 & 5 & 0 & 0 & 0 & 0 & 11 & 73.33 & 26.67 & $\begin{array}{c}7.91 \\
(6.78)\end{array}$ & 26.67 & 0.25 \\
\hline $\begin{array}{c}\text { Pyriproxyfen } \\
\text { LC }_{50}\end{array}$ & 0 & 2 & 4 & 3 & 0 & 0 & 9 & 56.25 & 43.75 & $\begin{array}{l}11.22 \\
(9.79)\end{array}$ & 43.75 & 29.68 \\
\hline Control & 15 & 12 & 0 & 0 & 0 & 0 & 27 & 100 & 0 & $\begin{array}{c}7.89 \\
(3.56)\end{array}$ & - & - \\
\hline
\end{tabular}

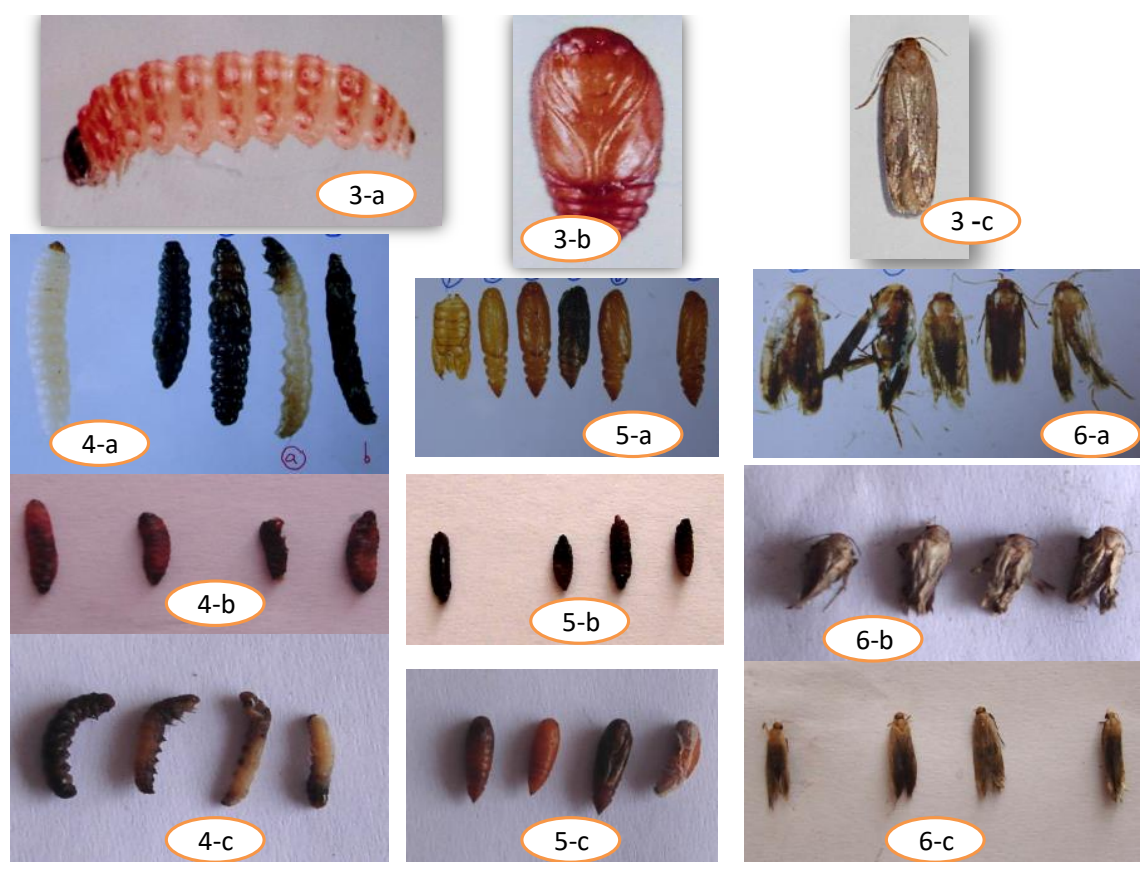

Fig. 3. developmental stages in untreated the cotton pink bollworm. (a) 4th instar larva. (b) Pupa, soon after pupation. (c) moth, soon after emergence.

Fig. 4. different morphological malformation in pink bollworm larvae fed on a diet treated with: 4a \&b: LC50 Abamectin 4c: LC50 Pyriproxyfen.

Fig. 5. different morphological malformation in pink bollworm pupae fed in the larval stage on a diet treated with: 5a \&b: LC50 Abamectin 5 c: LC50 Pyriproxyfen.

Fig. 6. different morphological malformation in pink bollworm moths fed in the larval stage on a diet treated with: 6a \&b: LC50 Abamectin 6 c: LC50 Pyriproxyfen 
Table 4. Effect of Abamectin and Pyriproxyfen on some biological aspects of the pink bollworm, Pectinophora gossypiella adult moth.

\begin{tabular}{|c|c|c|c|c|c|c|c|c|c|c|c|}
\hline \multirow{2}{*}{$\begin{array}{c}\text { Biological aspect } \\
\text { Formulation } \\
\end{array}$} & \multicolumn{6}{|c|}{$\begin{array}{l}\text { Number of adult emerged after } \\
\text { (days) }\end{array}$} & \multirow{2}{*}{$\begin{array}{l}\text { \% adult } \\
\text { emergent }\end{array}$} & \multirow{2}{*}{$\begin{array}{c}\% \\
\text { malformed } \\
\text { moths (\%) }\end{array}$} & \multirow{2}{*}{$\begin{array}{l}\text { adult } \\
\text { stage } \\
\text { /day }\end{array}$} & \multirow{2}{*}{$\begin{array}{l}\text { Reduction } \\
\text { in adult } \\
\text { stage (\%) }\end{array}$} & \multirow{2}{*}{$\begin{array}{c}\text { Rate of } \\
\text { increament } \\
\text { in adult } \\
\text { emergent }\end{array}$} \\
\hline & 19 & 21 & 23 & 25 & 27 & 29 & & & & & \\
\hline Abamectin $\mathrm{LC}_{50}$ & 0 & 7 & 4 & 0 & 0 & 0 & 81.82 & 18.18 & $\begin{array}{c}21.73 \\
(14.95)\end{array}$ & 18.44 & 18.18 \\
\hline $\begin{array}{l}\text { Pyriproxyfen } \\
\quad \text { LC }_{50}\end{array}$ & 0 & 7 & 2 & 0 & 0 & 0 & 88.89 & 11.11 & $\begin{array}{l}21.44 \\
(11.65)\end{array}$ & 36.44 & 11.11 \\
\hline Control & 10 & 5 & 2 & 10 & 0 & 0 & 100 & 0 & $\begin{array}{r}21.89 \\
(18.33) \\
\end{array}$ & - & - \\
\hline
\end{tabular}

Table 5. Effect of Abamectin and Pyriproxyfen on various biological aspects of the pink bollworm , Pectinophora gossypiella.

\begin{tabular}{|c|c|c|c|c|c|c|c|c|c|}
\hline $\begin{array}{c}\text { B.aspects } \\
\text { Formulation }\end{array}$ & $\begin{array}{c}\text { \% Larval } \\
\text { mortality }\end{array}$ & $\begin{array}{c}\text { \% Pupa- } \\
\text { tion }\end{array}$ & $\begin{array}{c}\text { \% Adult } \\
\text { emergent }\end{array}$ & $\begin{array}{c}\text { Larval } \\
\text { stage } \\
\text { (day) }\end{array}$ & $\begin{array}{c}\text { Pupal } \\
\text { stage } \\
\text { (day) }\end{array}$ & $\begin{array}{c}\% \\
\text { Adult } \\
\text { stage }\end{array}$ & $\begin{array}{c}\text { Malformed } \\
\text { larvae }\end{array}$ & $\begin{array}{c}\text { Malformed } \\
\text { pupae) }\end{array}$ & $\begin{array}{c}\text { Mal- } \\
\text { formed } \\
\text { moths }\end{array}$ \\
\hline $\begin{array}{c}\text { Abamectin } \\
\text { LC } \text { C }_{50}\end{array}$ & 50 & 73.33 & 81.82 & 1.13 & 6.78 & 14.95 & 13.33 & 26.67 & 18.18 \\
$\begin{array}{c}\text { Pyriproxyfe } \\
\text { n LC50 }\end{array}$ & 46.67 & 56.25 & 88.89 & 1.43 & 9.79 & 11.65 & 7.14 & 43.75 & 11.11 \\
Control & 10 & 100 & 100 & 4.33 & 3.56 & 18.33 & 0 & 0 & 0 \\
\hline
\end{tabular}

and $17.65 \%$ to the respective mentioned tested chemicals.

Some moths emerging from larvae fed on diet treated with $\mathrm{LC}_{50}$ Pyriproxyfen appeared with malformation exhibited as short curled or diverged wings, diverged forewings, malformed short antennae and /or deformed legs (Fig. 6 a \& b). Treatment with $\mathrm{LC}_{50}$ of Abamectin led to the emergence of some moths with some leg deformations while other moths emerged with undeveloped wings, (Fig. 6b).

\section{Effect of Abamectin and Pyriproxyfen on total protein content in $P$. gossypiella larvae}

Application of either $\mathrm{LC}_{50}$ Abamectin or Pyriporxyfen compounds to $P$. gossypiella larval diet caused an increase in protein content of treated larvae determined as $4^{\text {th }}$ instar larvae, being 44.25 and $33.71 \%$ respectively, more protein than in untreated larvae (control) (Fig. 7).

\section{Effect of Abamectin and Pyriproxyfen on $(\beta)$ Esterase Enzyme in P. gossypiella larvae}

Electrophoretic separation banding pattern presented in Table 6 and Fig. 8 show a wide change in density and intensity of $(\beta)$ esterase for the $P$. gossypiella larvae fed on a diet treated with either LC $_{50}$ Abamectin or Pyriporxyfen. The separated bands have wide variations as showed from bands no. 1, 2, 3, 4, 5 compared with band No. 6 Which appeared in control untreated insects. The results show that band of sample separated from larval treated with tested compounds (Fig. 5 \& Table 6) as follows.

Table 6. Number of $(\beta)$ esterase banding pattern of bollworm, $P$. gossypiella larvae affected by abamectin and pyriproxyfen.

\begin{tabular}{|c|c|c|c|}
\hline $\begin{array}{c}\text { Band } \\
\text { No. }\end{array}$ & $\begin{array}{c}\text { Tested com- } \\
\text { pound }\end{array}$ & Front & Type \# \\
\hline 1 & Abamectin & 0.209 & 0.209 \\
5 & Pyriproxyfen & 2.09 & 0.184 \\
6 & Control & 0.285 & 0.285 \\
\hline
\end{tabular}

(i) In case of Abamectin added as Lc 50 concentration the artificial diet of the larval stage had a high density and intensity band(no.3) .It is clear that the tested compounds affected the fragments of $(\beta)$ - Esterase in the tested larvae (band No. 1) for control.

(ii) In case of Pyriproxyfen added as Lc 50 concentration the artificial diet of the larval stage had a very low density and intensity band (no.2) .It is clear that the tested compounds affected the fragments of $(\beta)$ - Esterase in the tested larvae (band No. 1) for control. 


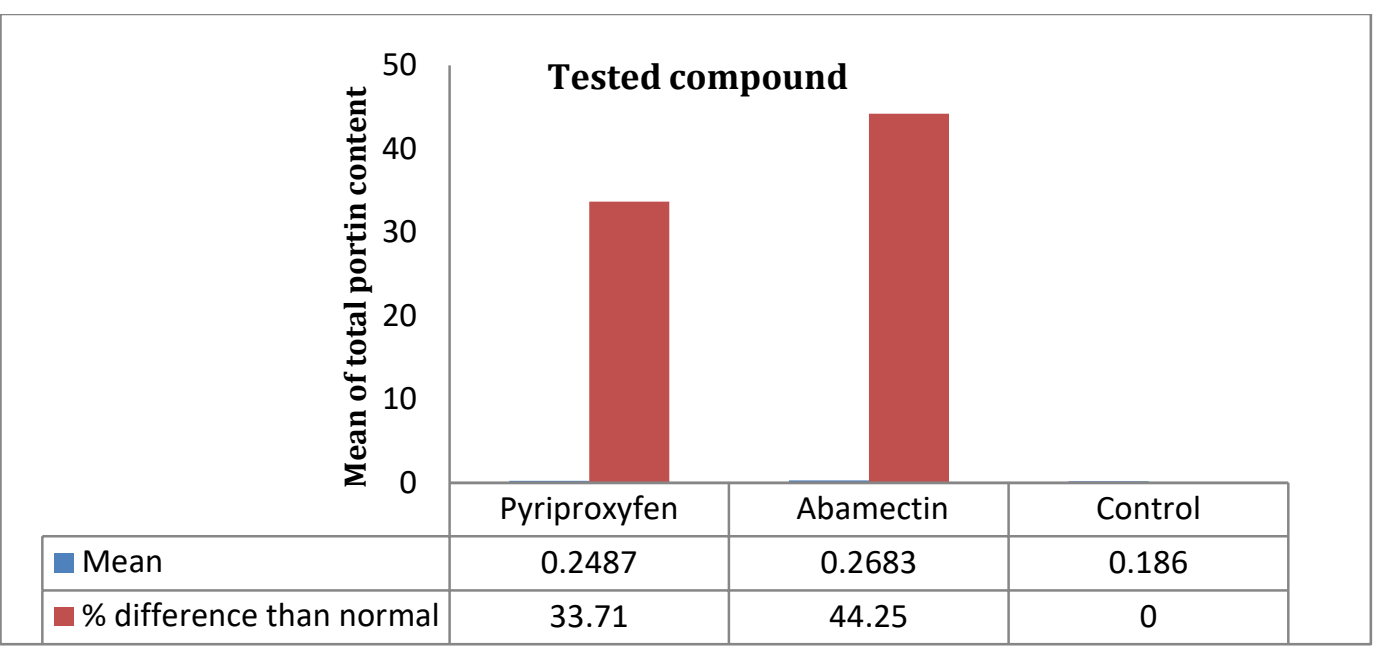

Fig. 7. Effect of pyriproxyfen, abamectine and plant extracts of dumb-cane and bestachia on total protein content $4^{\text {th }}$ instar larvae of P.gossypiella.

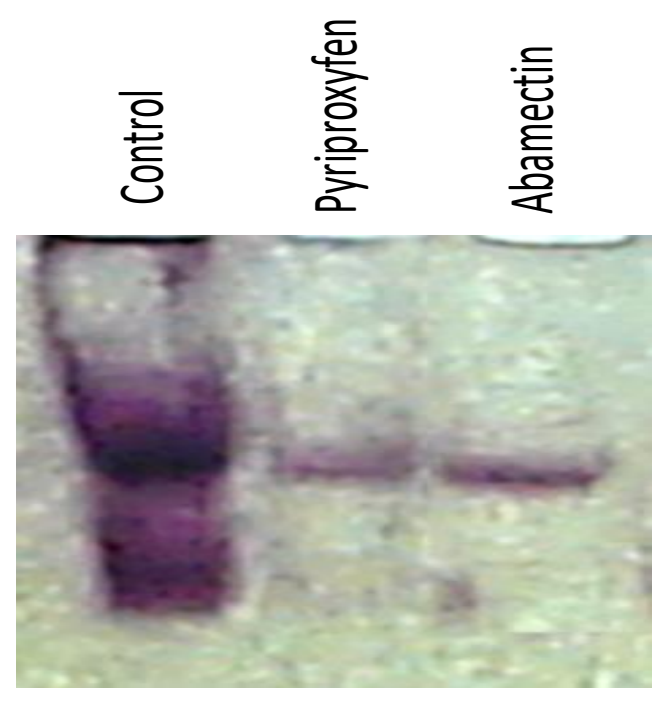

Fig. 8. Polyacrylamideg el profiles of Esterase $(\beta)$ of the $4^{\text {th }}$ instar larvae in P.gossypiella treated with Abamectin and pyriproxyfen.

\section{DISCUSSION}

Based on the obtained results, it was demonstrated that $1^{\text {st }}$ instar larvae of the pink bollworm $P$. gossypiella was more susceptible to Abamectin than to Pyriproxyfen as exhibited by the $\mathrm{LC}_{50}$ values. Such finding may be due to the relative rapid action of Abamectin which may attributed to its mode of action as a neurotoxic insecticide which affected the $\gamma-$ amino butyric acid (GABA) receptor and block the GABA- gated chloride channel in the affected larval brain (Bloomquist, 1996 and Ray-
mound-Delpech et al 2005). Similar results were reported in other insects treated with similar compounds, e.g. Pectinophora gossypiella, and Earias insulana (Glancey et al 1982 and Meola et al 1996 \& 2001). Meanwhile, the lower toxicity or the action of Pyriproxyfen to the targeted insects may be attributed to its action as juvenile hormone mimic (juvenoid) that interfere with the hormonal balance at the molting process as suggested by Dhadialla et al (1998).

Morphological deformations were observed in larvae and the subsequent developmental stages, pupae and adults following feeding of larvae on artificial media treated with $\mathrm{LC}_{50}$ of tested compounds. Pupation and adult emergence was found to be delayed or inhibited. Treatment of $P$. gossypiella with the Pyriproxyfen did not cause an extra molt but caused failure or incomplete ecdysis. Similar descriptions were found in other insects treated with juvenoids, e.g. Chilo suppressalis (Mitsui et al 1973) and $P$. gossypiella (Cawich et al 1974), Antonious et al (1987) and $S$. littoralis (Shenouda et al 2002). Physiologically, "morphological response" occurs only when juvenile hormone remains in the body until the end of the period in which all cells were still sensitive to this hormone. The exogenous molecule may interfere with developmental sequence or metamorphosis.

$P$. gossypiella, newly hatched larvae reared on an artificial diet treated with LC $_{50}$ Pyriproxyfen led to an increase in total body protein content than their equivalent control. The obtained results are also in agreement with those reported by ElSweerki (2003) who described an increase in the number of protein bands in the electrophoresis 
pattern extracted from the eggs of $S$. littoralis treated $\mathrm{LC}_{50}$ of Pyriproxyfen. The biochemical studies also showed the effect of Abamectin and Pyriproxyfen on the enzyme $\beta$-esterase activity in treated $P$. gossypiella larvae. Mohamed (1994) mentioned that abamectin caused inhibitory effect on the activity of both $\alpha$-esterase and $\beta$ - esterase in $S$. littoralis larvae less by $28 \%$ than their control. The great reduction in $\beta$ - esterase enzyme by Pyriproxyfen in $P$. gossypiella larval stage was very clear in comparison to control insects. Rizk (1998) reported that Vertimec and Neemazal affected the activities of both $\alpha$-esterase and $\beta$ - esterase of both $E$. insulana and $P$. gossypiella and that esterase in the tested larvae were very inactive than the controls.

\section{REFERENCES}

Abbott, W.S. 1925. A method for computing the effectiveness of an insecticide .J. Econ. Entomol., 18, 265- 267.

Abdel-Hafez, Alia, Metwally, A.G. and Saleh, M.R.A. 1982. Rearing pink bollworm Pectionophora gossypiella. (Saund.), on kidney bean diet in Egypt (Lepidoptera: Gelechiidae). Res. Bull. Fac. Agric., Zagazig Univ. 579, 10110.

Antonious, A.G., Mariy, F.M., Hegazy, G.M. 1987. Juvenilizing Action of 2 (L-Methyl 1-2 (4 Phenoxy-phenoxy) ethoxy pyridine on the Egyptian cotton leafworm. Spodoptera littoralis (Boisd). $2^{\text {nd }}$ Nat. Conf. of Pests \& Disease. Veg. \& Fruits, Ismailia, pp, 428-440.

Bloomquist, J.R. 1996. Ion channels as targets for insecticides. Annu. Rev. Entomol. 41, 163-190.

Bradford, M.M. 1976. A rapid and sensitive method for the quantization of microgram quantities of protein utilizing the principle of protein-Dye binding. Annal. Biochem., 72, 248-254.

Campbell, W.C. 1989. Invermectin and Abamectin (Eds.), edited by Springer Verlage, New York.

Cawich, A., Crowder, L.A. and Watson, T.E. 1974. Effects of juvenile hormone mimic on the pink bollworms. J. Econ. Entomol. 67, 173076.

Dhadialla, T.S., Carlson, G.R. and Le, D.P. 1998. New insecticides with ecdysteroidal and juvenile hormone activity. Ann. Rev. Entomol. 43, 545-569.

El-Sweerky, Fatma El-Zahraa. 2003. Ovicidal activity of natural and synthetic compounds against cotton leafworm. M.Sc. Thesis, Inst. of Enviro. Stud. and Res. Ain Shams Univ., Egypt, 143 p.
Farag, A.M.A. 2001. Biochemical studies on the effect of some insect growth regulators on the cotton leafworm. M.Sc. Thesis, Fac. of Agric., Cairo Univ., Egypt, 180 p.

Finney, D.J., 1972. Probi analysis. Cambridge University Press.Cambridge, pp. 333.

Gaaboub, I.A., El-Kady, H.A., El-Khayat, E.F. and El-Sheekwy. A.A. 2012. Biochemical and histological effect of some plant extracts, insecticide (methomyl) and bio insecticide (protecto) against cotton leafworm, Spodoptera littoralis (Boisd.). $1^{\text {st }}$ Inter. Conf. Biotech. Aplic. Agric. Benha Univ., Moshtohor. Egypt Bio-Pest. Tech. pp. 21-32.

Glancey, B.M., Lofgren, C.S. and Williams, D.F. 1982. Avermectin B1a: effects on the ovaries of red imported fire ant queens (Hymenoptera: Formicidae). J. Med. Entomol. 19, 743-747.

Halley, B.A., William, J.A., Heuvel, V. and Wislocki, P.G. 1993. Environmental effects of the usage of avermectines in livestock. Veter. Parasit. 48, 109-125.

Krypsin-Sorensen, I., Gelbic, I. and Slama, K. 1977. Juvenoid action on the total body weight metabolism in larvae of Noctuidae moth. J. Insect Physiol., 23, 531-535.

Lewis, E.E., Selvan, S., Campbell, J.F. and Gaugler, R. 1994. Changes in foraging behaviour during the infective stage of entomopathogenic nematodes. Parasitology 110, 583-590

Meola, R.W., Dean, S.R. and Bhaskaran, G. 2001. Effects of juvenile hormone on eggs and adults of the cat flea (Siphonaptera: Pulicidae). J. Med. Entomol., 38(1), 85-92

Meola, R., Pullen, S. and Meloa, S. 1996. Toxicity and histopathology of the growth regulators pyriproxyfen to adults and eggs of the cat flea (Siphonaptera: Pulicidae). J. Med .Entomol. 33, 670-679.

Mitsui, T., Nobusawa, C., Fukam, J., Mori, K. and Fukamaga, K. 1973. Compounds with juvenile hormone activity: Inhibitory effects of the synthetic juvenile hormone and it's analogues on the metamorphosis of several insects. Appl. Entomol. Zool., 8, 27-35.

Mohamed, L.T. 1994. Toxicological and biochemical studies on the effect of some new pesticides against cotton leaf worm. M.Sc. Thesis, Fac. Agric., Minoufyia Univ., Shebin El-Kom. Egypt. 248, p.

Mostafa, S.A. 1993. Biochemical effects of some chemical compounds on Spodoptera littoralis (Boisd.). Ph. D. Thesis, Fac. Agri., Al-Azhar Univ., Egypt. 193, p.

Oerk, E.C., Dehne, H.W., Shonbeck, G. and Weber, A. 1994. Crop Protection: Estimated loses in major food and cash crops. El Sevier Sci- 

bollworm, Pectinophora gossypiella (saund.)

ences B.V., Amesterdam, 880 p. Pacific Entomol. 2, 39-44.

Quistad, G.B., Staiger, L.E. and Schooley, D.A. 1974. Environmental degradation of the insect growth regulator methoprene isopropyl (3E, $A E)$ - 11-methoxy-3,7, 11-trimethyl-2,4-dodecadienoate.1. metabolism by alfalfa and rice. J. Agric. Food Chem. 22, 582-589.

Raymond-Delpech, V., Matsuda, K., Sattelle, B.M., Rauh, J.J. and Sattelle, D.B. 2005. Ion channels: molecular targets of neuroactive insecticides. Invert. Neurosci. 5, 119-133.
Rizk, S.M.T. 1998. Biochemical and histochemical studies on effect of natural products on some cotton pests. Ph.D. Thesis, Fac. of Agric., Al-Azhar Univ., Egypt. 176, p.

Shenoda, M.L., Farrag, R.M. and Salem, D.M. 2002. Efficacy of the botanical extract (myrrh), chemical insecticides and their combination on the cotton leaf worm Spodoptera littoralis (Boisd.). J. Environ. Sci. (B) 35, 347-356.

Staal, G.B. 1982. Insect control with growth regulators interfering with the endocrine system. Entomol. Exper. Appl. 31, 15-23. 